Section Editor Mitchell S.V. Elkind, MD, MS

\section{Teaching NeuroImages: Seeing double}

\section{Intercavernous sinus dural arteriovenous fistula causing bilateral abducens palsy}

\section{J.F. Huang, MD \\ M. Toledano, MD \\ B.S. Katz, MD \\ G. Lanzino, MD \\ B.D. Moseley, MD}

Correspondence \& reprint requests to Dr. Moseley: moseley.brian@mayo.edu

\section{Figure 1 Magnetic resonance angiography (MRA) brain}

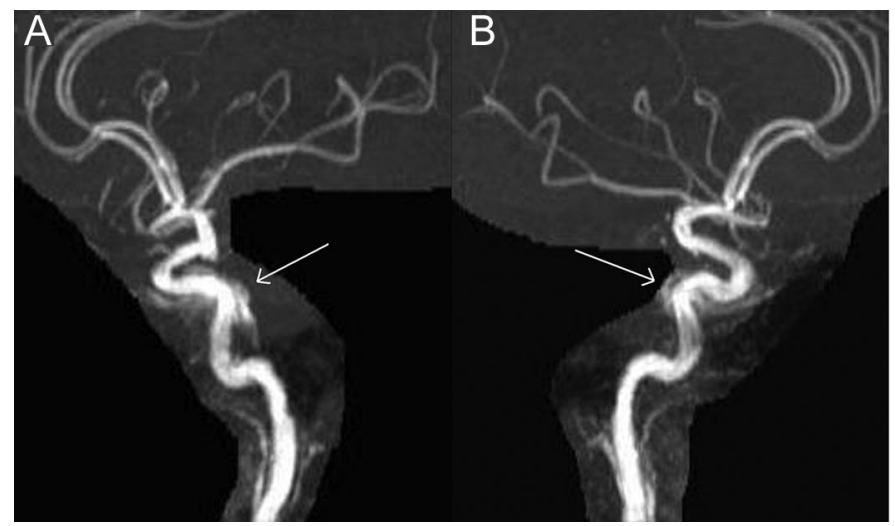

MRA revealed flow-related enhancement in the right (A) and left (B) cavernous sinuses (arrows) suggestive of carotid cavernous fistulas.

A 64-year-old woman developed sudden onset of diplopia, headache, and bilateral abducens palsy. MRI revealed no intracranial mass, ischemia, or intraorbital pathology. Magnetic resonance angiography suggested bilateral carotid cavernous fistulas (CCFs, figure 1). Digital substraction angiogram revealed an intercavernous sinus dural arteriovenous fistula (DAVF), which was successfully embolized (figure 2). By 3-month follow-up, her abducens palsies and diplopia had resolved.

Bilateral abducens palsy can occur in the setting of a CCF or an intercavernous sinus DAVF. Such palsies are likely secondary to direct compression, vascular steal with cranial nerve ischemia, or swelling of extraocular muscles secondary to venous congestion. ${ }^{1,2}$

\section{AUTHOR CONTRIBUTIONS}

Drs. Huang and Moseley made substantive contributions to the design of the study and drafting of the manuscript. Drs. Toledano and Katz made substantive contributions to the revision of the manuscript. Dr. Lanzino made substantive contributions to the design of the study and revision of the manuscript.

\section{REFERENCES}

1. Lee KY, Kim SM, Kim DI. Isolated bilateral abducens nerve palsy due to carotid cavernous dural arteriovenous fistula. Yonsei Med J 1998;39:283-286.

2. Loumiotis I, Cloft HJ, Lanzino G. Intercavernous sinus dural arteriovenous fistula successfully treated with transvenous embolization. a case report. Interv Neuroradiol 2011;17:208-211.

From the Departments of Neurology (J.F.H., M.T., B.S.K., B.D.M.) and Neurosurgery (G.L.), Mayo Clinic, Rochester, MN. 
Figure 2 Cerebral angiogram

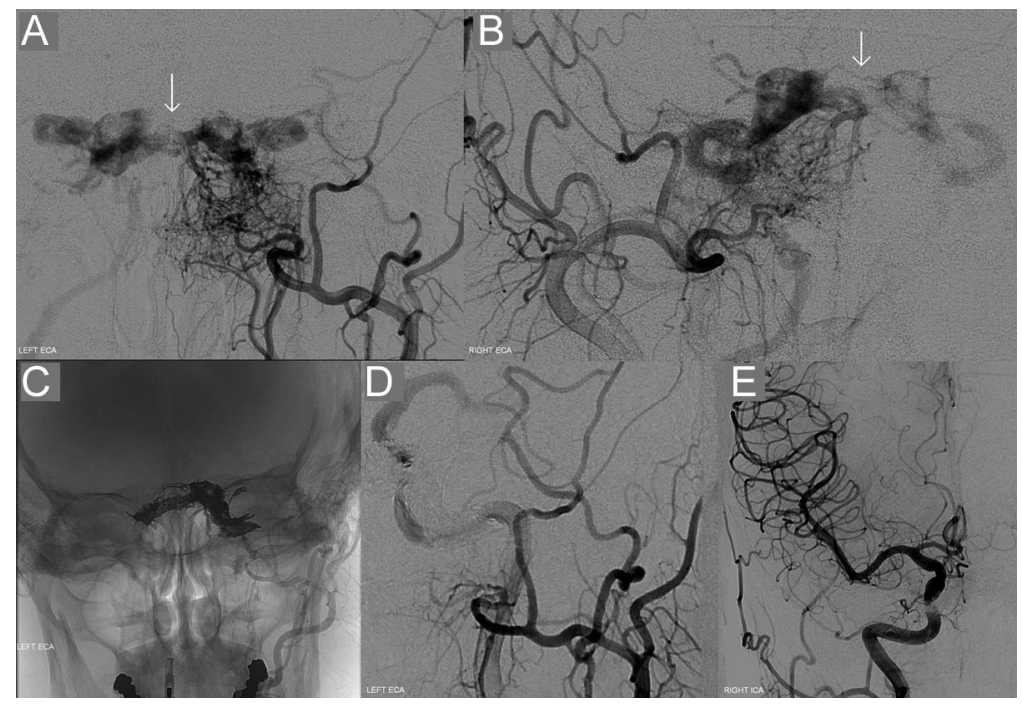

Angiogram of the left (A) and right (B) external carotid arteries revealed a dural arteriovenous fistula of the intercavernous sinus (arrows). Following embolization (C), no residual fistula remained $(D, E)$. 


\section{Neurology}

Teaching NeuroImages: Seeing double: Intercavernous sinus dural arteriovenous

fistula causing bilateral abducens palsy

J.F. Huang, M. Toledano, B.S. Katz, et al.

Neurology 2012;78;e95-e96

DOI 10.1212/WNL.0b013e31824f80a5

\section{This information is current as of April 9, 2012}

\section{Updated Information \&} Services

References

Subspecialty Collections

Permissions \& Licensing

Reprints including high resolution figures, can be found at: http://n.neurology.org/content/78/15/e95.full

This article cites 2 articles, 0 of which you can access for free at: http://n.neurology.org/content/78/15/e95.full\#ref-list-1

This article, along with others on similar topics, appears in the following collection(s):

\section{All Cerebrovascular disease/Stroke}

http://n.neurology.org/cgi/collection/all_cerebrovascular_disease_strok e

All Neuro-ophthalmology

http://n.neurology.org/cgi/collection/all_neuroophthalmology

Arteriovenous malformation

http://n.neurology.org/cgi/collection/arteriovenous_malformation Diplopia (double vision)

http://n.neurology.org/cgi/collection/diplopia_double_vision Ocular motility

http://n.neurology.org/cgi/collection/ocular_motility

Information about reproducing this article in parts (figures,tables) or in its entirety can be found online at:

http://www.neurology.org/about/about_the_journal\#permissions

Information about ordering reprints can be found online:

http://n.neurology.org/subscribers/advertise

Neurology ${ }^{\circledR}$ is the official journal of the American Academy of Neurology. Published continuously since 1951, it is now a weekly with 48 issues per year. Copyright Copyright @ 2012 by AAN Enterprises, Inc.. All rights reserved. Print ISSN: 0028-3878. Online ISSN: 1526-632X.

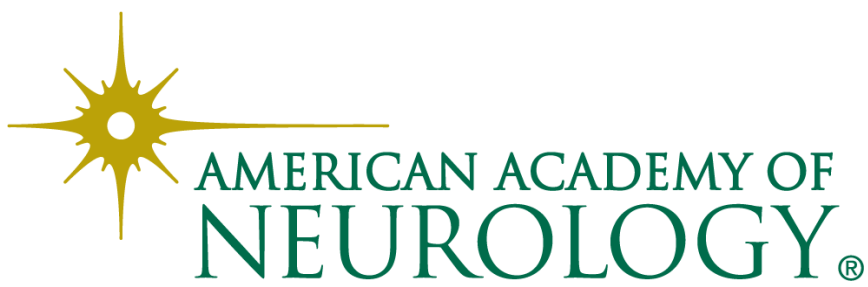

